\title{
Public-Private Mix Implementation and Achievements of Tuberculosis Control Program at Puskesmas in Pekanbaru
}

Implementasi Public-Private Mix dan Capaian Program Pengendalian Tuberkulosis di Puskesmas Pekanbaru

\author{
Elda Nazriati ${ }^{*}$, Zulharman ${ }^{1}$, Fifia Chandra ${ }^{2}$, Ucha Anggiani Putri ${ }^{3}$ \\ ${ }^{1}$ Department of Medical Education and Family Medicine, Faculty of Medicine, Universitas Riau \\ 2 Department of Public Health and Community Medicine, Faculty of Medicine, Universitas Riau \\ ${ }^{3}$ Faculty of Medicine, Universitas Riau
}

DATA OF ARTICLE:

Received: 08 May 2021

Reviewed: 06 June 2021

Revised:25 June 2021

Accepted: 05 July 2021

*CORRESPONDENCE:

eldanazriati@gmail.com

DOI:

10.18196/mmjkk.v21i2.11731

TYPE OF ARTICLE:

Research
Abstract: Public-Private Mix (PPM) is a strategy implemented in countries with a high burden of tuberculosis, including Indonesia. This study aims to identify PPM implementation at the Puskesmas and the success of the TB control program at the Puskesmas that have implemented the PPM strategy. The research was conducted in 2019 in Pekanbaru Municipality. It was an observational study that collected quantitative and qualitative data. The implementation of PPM was assessed through guided interviews. The success of the Tuberculosis control program was assessed through the Case Notification Rate and Success Rate using secondary data from 2010 to 2017. The results showed that PPM had been implemented in six health centers in Pekanbaru. However, there were obstacles such as a lack of human resources, NGOs, private clinics, and local governments. The Case Notification Rate and Success Rate showed an increasing trend after the PPM implementation. However, these indicators had not yet reached the national target. It can be concluded that PPM in Pekanbaru had been implemented but needed to be improved at all Puskesmas by involving more partnerships and following up on obstacles encountered. Furthermore, the Tuberculosis Control Indicator had shown an increasing trend, but it needed to reach the national target.

Keywords: achievements; public-private mix; tuberculosis

Abstrak: Public Private Mix (PPM) adalah strategi yang dilaksanakan di negara dengan beban Tuberkulosis tinggi termasuk Indonesia. Perlu dilakukan analisis bagaimana implementasi PPM serta capaian indikator pengendalian Tuberkulosis. Tujuan penelitian ini adalah untuk mengetahui implementasi PPM di Puskesmas serta keberhasilan program pengendalian TB paru pada Puskesmas yang telah menerapkan strategi PPM. Penelitian dilakukan tahun 2019 di Kota Pekanbaru. Penelitian ini bersifat observasional yang mengumpulkan data kuantitatif dan kualitatif. Implementasi PPM dinilai melalui wawancara terpimpin. Keberhasilan program pengendalian Tuberkulosis dinilai melalui angka notifikasi kasus dan angka keberhasilan pengobatan menggunakan data sekunder dari tahun 2010 hingga 2017. Hasil penelitian menunjukkan PPM telah diterapkan di 6 puskesmas di Pekanbaru, namun terdapat kendala seperti kurangnya sumber daya manusia, kurangnya keterlibatan LSM, klinik swasta, dan pemerintah daerah. Case Notification Rate dan Succsess Rate menunjukkan tren peningkatan setelah penerapan PPM, namun belum mencapai target nasional. Dapat disimpulkan bahwa PPM di Pekanbaru telah dimplementasikan tetapi perlu ditingkatkan pada seluruh Puskesmas dengan melibatkan lebih banyak mitra dan menindaklanjuti hambatan yang dihadapi. Indikator Pengendalian Tuberkulosis sudah menunjukkan tren peningkatan, namun perlu mencapai target nasional

Kata Kunci: capaian; public private mix; tuberkulosis 


\section{INTRODUCTION}

Based on the World Health Organization (WHO) reports, Indonesia is one of the five countries with the highest tuberculosis (TB) cases. ${ }^{1}$ In 2017, Indonesia had 425,089 TB cases. ${ }^{2}$ Indonesia is a country with a large private health sector that is not yet firmly linked to the National Tuberculosis Control Program (NTP). The overall level of underreporting of detected TB cases was estimated to be $41 \%{ }^{3}$

One of the targets to be achieved in the Sustainable Development Goals (SDGs) is to end the tuberculosis epidemic. The global prime ministerial conference on End-TB aims to accelerate progress towards the targets set in the SDGs and End-TB through a multisectoral role. The WHO End-TB Strategy calls for close collaboration with affected communities and civil society organizations in planning, implementing, monitoring, and evaluating. ${ }^{3}$ Public Private Mix (PPM) is a strategy for expanding TB services by involving all health service providers, both private and public, using international standard TB treatment. ${ }^{4}$ Public-Private Mix is considered relevant to be implemented in countries with high TB burden in Asia and Africa. The World Health Organization (WHO) reports that the contribution of PPM to TB notification between 2012 and 2016 increased by more than $10 \%$ in Indonesia, Bangladesh, India, and the Philippines. ${ }^{1}$

The expansion of the Directly Observed Treatment Short-course (DOTS) strategy with the PPM approach in Indonesia has been carried out since 2000. In 2006, Indonesia became the first country among countries with a high burden of TB in Southeast Asia to achieve the Millennium Development Goals (MDGs) target of 70\%; the discovery of new cases of Acid Fast Bacilli (AFB) was positive and achieved $85 \%$ recovery. The Pekanbaru Municipality Health Office had launched a PPM strategy since 2009, and Puskesmas was one of the health service facilities involved. Based on the information provided by the Pekanbaru City Health Office, in 2019, there were six Puskesmas in Pekanbaru that already had a Cooperation document (MoU) with other health facilities. To get an overview of the success of the PPM strategy, it is necessary to analyze how the PPM implementation in Pekanbaru and the achievements of the TB program before and after the implementation of PPM.

The success of the TB control program can be assessed using two leading indicators of the national TB control program, namely the Case Notification Rate and the Success Rate. The number of case notifications collected serially will illustrate increasing or decreasing TB patient findings in a region. The success rate for treatment has a target that must be achieved, namely at least $90 \%{ }^{6}$ Puskesmas have an essential role in increasing notification at the First Level Health Facility (FKTP) as they have the authority to coordinate and foster FKTPs in their area. (5) As one of the FKTPs, Puskesmas also plays a role in TB treatment without complications. ${ }^{6}$

PPM is a promising strategy to strengthen global TB care and control but is affected by contextual characteristics in different areas. The scaling-up of PPM should contain essential commonalities, particularly substantial financial support, and continuous material input. Additionally, it is essential to improve program governance and training for the health providers involved through integrated collaborative mechanisms. ${ }^{7}$

This study aims to describe the implementation of PPM in Puskesmas and the success of pulmonary tuberculosis control programs at Puskesmas, which has implemented PPM strategies in Pekanbaru Municipality.

\section{MATERIALS AND METHOD}

This study was an observational study that collected quantitative and qualitative data. Quantitative data included the trend of the achievement of the Tuberculosis control program at the Puskesmas before and after the implementation of the public-private mix, while the qualitative data were a description of the Implementation of the public-private mix at the Puskesmas. Qualitative and quantitative data were taken at the same time. These two data complemented each other to understand the research results. The research was conducted in the city of Pekanbaru in 2019. The population of the study was the health centers that had implemented PPM in Pekanbaru. The inclusion criteria included Puskesmas that already have an MOU on PPM implementation and have implemented PPM for at least one year. Puskesmas that did not report the achievements of the TB program regularly and were not willing to be interviewed and provided secondary data were included in the exclusion criteria. Pekanbaru had 20 health centers, six of which met the inclusion criteria and were taken as research samples.

The implementation of PPM at the Puskesmas was assessed qualitatively through guided interviews using an interview guide. The interview guidelines contained the roles, constraints, and proposed solutions in implementing PPM. Validation Guidelines for interviews were conducted with expert judgment. The research informants consisted of doctors at the Puskesmas, the Head of the Puskesmas, the Manager of the 


\section{mutiara \\ medika}

Puskesmas TB Program, and other parties mentioned by the informants. Interviews were conducted using a recording device. Interview data were transcribed in verbatim form and content analysis was carried out. The achievements of the TB program were assessed quantitatively based on two indicators, namely the case notification rate and the success rate, collected through document searches at the Puskesmas and the Pekanbaru Municipality Health Office. Data included the report on the last period of the TB Puskesmas Program available at the time of the study.

Content analysis on qualitative data was carried out by determining keywords, sub-themes, and themes. Themes were determined based on research questions, including the roles of various parties in implementing the public-private mix and obstacles and solutions encountered based on interviews with research respondents. Validity and reliability were carried out through triangulation of sources and interrater reliability. Quantitative data were processed using a computer device to see the achievements of the Puskesmas and see the trend of increasing or decreasing before and after the implementation of PPM. Trend analysis was carried out using linear regression, which inputted the average achievement of each indicator of the TB program every year, starting in 2010-2017. This study was approved by all authors. This research procedure has ethical clearance from the medical research ethics committee of the Faculty of Medicine, Riau University number 020 / UN19.5.1.1.8 / UEPKK / 2019.

\section{RESULT}

In 2019, six out of 20 Puskesmas in Pekanbaru had implemented PPM. The six Puskesmas started PPM at various times, some started in 2014, and some started PPM in 2016. The total population served by each Puskesmas was 34,995 to 115,333. The number of TB cases in each Puskesmas was 23 to 155 cases. Informant interviews showed the roles of various parties in tuberculosis PPM, which were listed in Table 1. In the implementation of PPM Tuberculosis in Puskesmas, several obstacles and solutions were proposed based on interviews with informants described in Table 2.

Table 1. Roles of Various Parties in Implementing PPM

\begin{tabular}{|c|c|c|}
\hline No & Network member & Role \\
\hline 1 & Pekanbaru Health office & $\begin{array}{l}\text { make a policy and form the PPM team } \\
\text { conducted training for the PHC } \\
\text { recommend private clinics to collaborate with PHC } \\
\text { facilitate cooperation with various parties } \\
\text { monitor PPM implementation }\end{array}$ \\
\hline 2 & Head of PHC & $\begin{array}{l}\text { sign the MoU } \\
\text { form the PPM implementation program }\end{array}$ \\
\hline 3 & DOTs Team in PHC & $\begin{array}{l}\text { invite private clinics to socialize TB PPM } \\
\text { make an MoU and coordinate with private clinics } \\
\text { collect data from private clinics in the working area and make } \\
\text { reports to the health department office }\end{array}$ \\
\hline 4 & Private clinics & $\begin{array}{l}\text { select TB suspects and refer to PHC } \\
\text { reported new TB patients to PHC } \\
\text { carry out TB treatment in the clinic }\end{array}$ \\
\hline 5 & Community & $\begin{array}{l}\text { Social health workers conduct patient selection and refer to PHC } \\
\text { (only in two PHC) } \\
\text { The local government coordinates with the subordinates for program } \\
\text { socialization (if necessary) }\end{array}$ \\
\hline
\end{tabular}


Table 2. Constraints and Solutions in PPM Implementation based on Interviews

\begin{tabular}{|c|c|c|c|}
\hline \\
\hline No & Aspect & Barriers & Solutions \\
\hline 1 & human Resources & Move to another place or other duties & $\begin{array}{l}\text { Policy from the clinic, PHC, and district } \\
\text { health officer }\end{array}$ \\
\hline \multirow{3}{*}{2} & \multirow{3}{*}{ External Network } & $\begin{array}{l}\text { Lack of number } \\
\text { workload }\end{array}$ & Ask a peer to help at PHC \\
\hline & & $\begin{array}{l}\text { Lack of training } \\
\text { lack of communication with PHC officers }\end{array}$ & $\begin{array}{l}\text { More training conducted } \\
\text { increase PPM socialization and ask clinics } \\
\text { and independent practice Physicians to } \\
\text { send patients to PHC actively }\end{array}$ \\
\hline & & $\begin{array}{l}\text { did not refer the patient to PHC and did not } \\
\text { want to treat TB patients }\end{array}$ & $\begin{array}{l}\text { Provides TB drug programs in clinics and } \\
\text { private practice doctors }\end{array}$ \\
\hline & & $\begin{array}{l}\text { lack of community participation and local } \\
\text { government }\end{array}$ & $\begin{array}{l}\text { Improve socialization about the role of } \\
\text { the community and local government in } \\
\text { the implementation of PPM }\end{array}$ \\
\hline 3 & Administration & $\begin{array}{l}\text { Patients do not live in the PHC work area so } \\
\text { that contact screening is difficult to do }\end{array}$ & $\begin{array}{l}\text { feedback to } \mathrm{PHC} \text { in the work area where } \\
\text { the patient lives to carry out contact } \\
\text { investigation }\end{array}$ \\
\hline
\end{tabular}

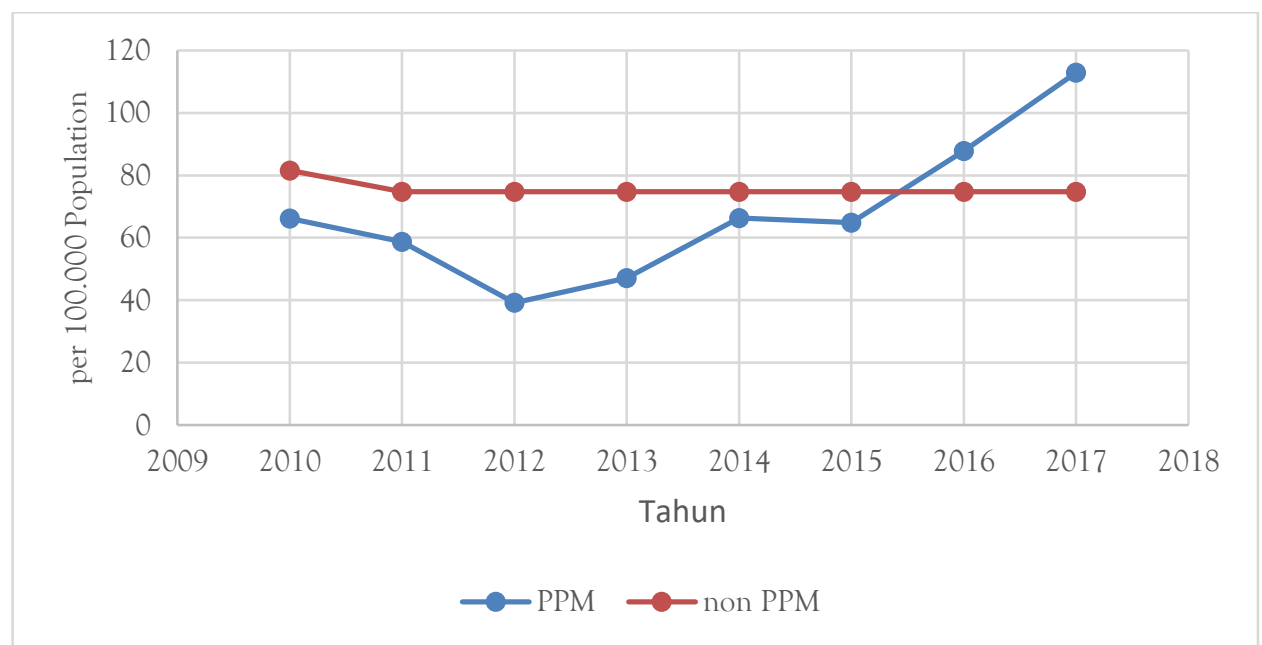

Figure 1. Case Notifications rate at Puskesmas that has implemented PPM and those who have not implemented PPM

The indicators of the success of the tuberculosis control program in this study were case notification and treatment success. Figure 1 compares the average case notifications at Puskesmas that had implemented PPM and those that had not during 2010-2017.

Figure 2 shows the trend of the average number of case notifications before and after PPM implementation at six Puskesmas in Pekanbaru. A comparison of the success rates of tuberculosis treatment at Puskesmas that both has and has not implemented PPM is shown in Figure 3. The trend of the average success rate of tuberculosis treatment at Puskesmas that has implemented PPM is presented in Figure 4 


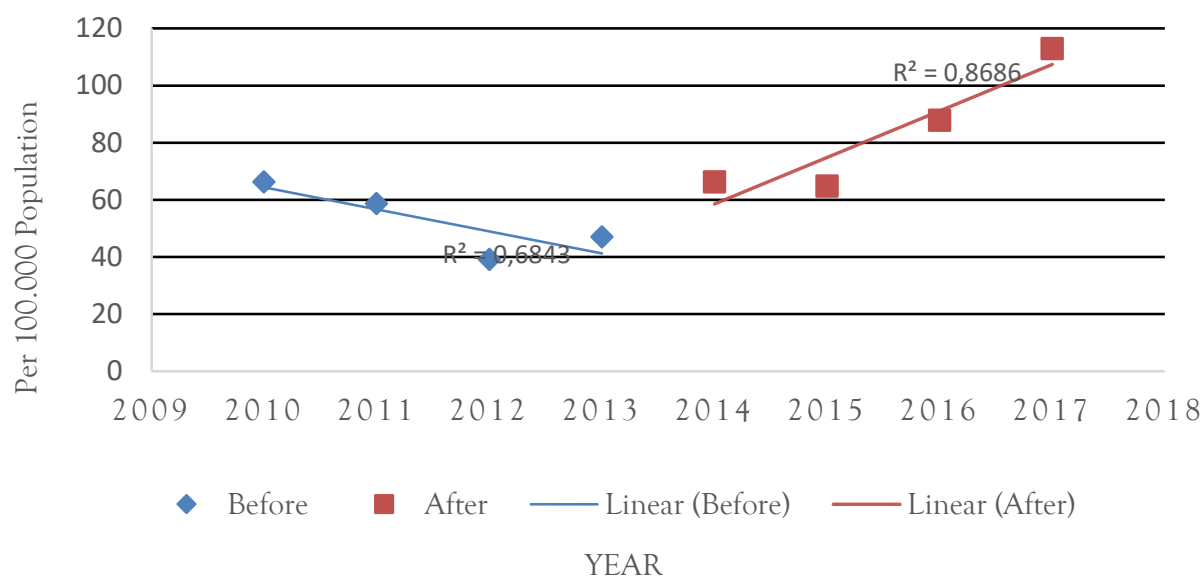

Figure 2. The trend of notification rate before and after implementing PPM at 6 Puskesmas in Pekanbaru

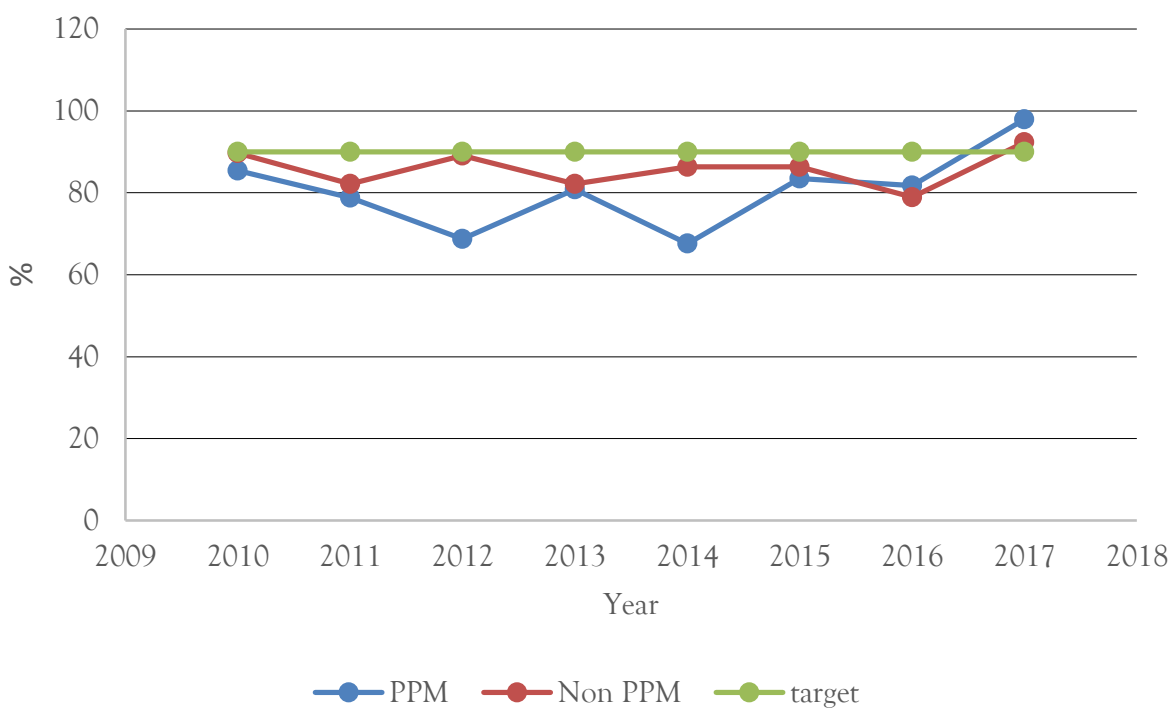

Figure 3. Comparison of Treatment Success Rates at Puskesmas that has Implemented PPM and those that have not implemented PPM

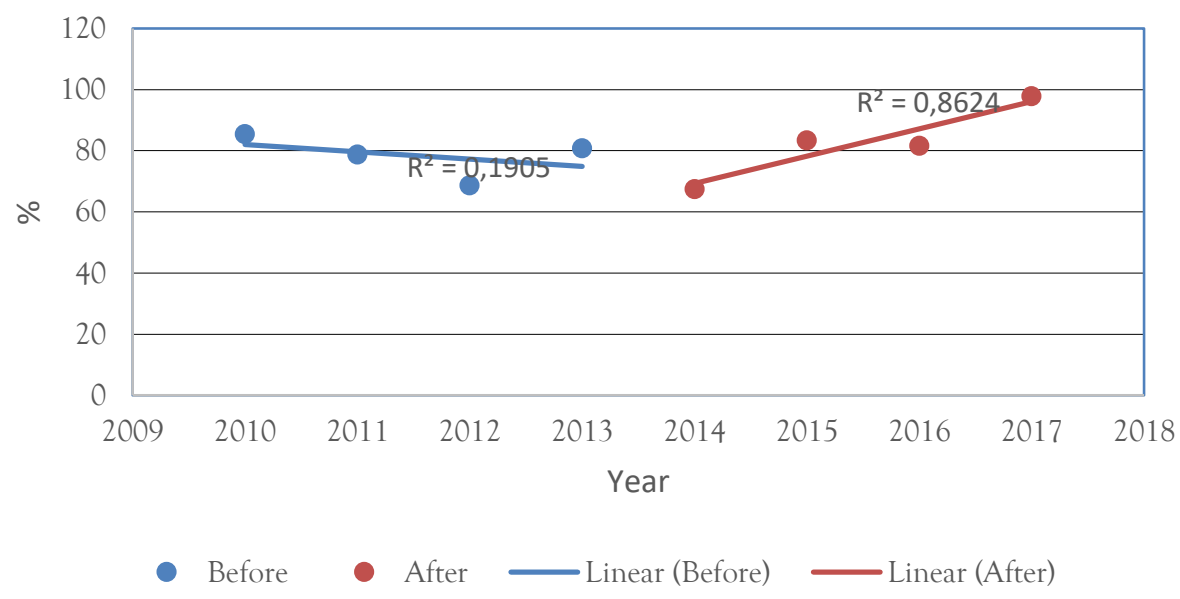

Figure 4. Trends in the Success Rate of Treatment before and after the implementation of PPM at 6 Puskesmas in Pekanbaru 


\section{DISCUSSION}

The implementation of PPM in Pekanbaru began in 2014. The City Health Office carried out the PPM socialization, followed by a cooperation agreement between the Puskesmas and the private sector. Some of the parties that play a role in implementing PPM are the City Health Officer, the Head of the Puskesmas, the DOTS Team, Private Clinics, and the Community. There are several obstacles in implementing PPM, such as human resources, external networks, and administrative factors. PPM in Indonesia has been implemented with District-Based PPM (DPPM) under the coordination of District / City Health Offices. The Puskesmas is an essential part of the primary service component in DPPM as it has the authority to coordinate and foster primary service facilities in its working area. Puskesmas plays a role in establishing internal and external networks. The role of the Puskesmas in the external network is to coordinate and foster independent medical practices, primary care clinics, pharmacies, and private laboratories in their working areas. ${ }^{5}$

Seven crucial steps in building a PPM Partnership consist of preparing a document and gap analysis, sensitizing, socializing, meeting with the institution's board of directors, conducting workshops to select improvement opportunities, signing collaborative agreements, formulating a monitoring plan and evaluating the results. ${ }^{4}$ The implementation of PPM in six Puskesmas in Pekanbaru is in line with the Strategic Guidelines for Building Public-Private Cooperation (PPM) to Support Tuberculosis Control, starting with the outreach from the District Health Office about PPM, suggestions for collaborating with other health facilities in the working area of the Puskesmas, a meeting between Puskesmas to explain the DOTS PPM program, discussion of decision making about the type of cooperation to be carried out, the establishment of an MoU between Puskesmas and private sectors, and the implementation of the MoU. PPM is based on two main concepts. First, the public sector negotiates contracts with private health facilities to determine the tasks. Second, these intermediary organizations seek individual providers, mediate between the public and private sectors, carry out gathering and engaging with individual providers, notify cases of TB program managers, and coordinate with administrators for free drugs and follow-up. ${ }^{8}$

This study showed that some of the obstacles faced in implementing PPM include aspects of human resources, external networks, and patients who live outside the working area of the Puskesmas. Problems in human resources include the number of officers, transfer of officers to other health centers or other tasks, lack of training, and workload. It was consistent with several studies in Indonesia ${ }^{9}$, Ethiopia ${ }^{10}$, and South Africa. ${ }^{11}$ Several factors have caused PPM implementation to be not optimal in Ende Regency, Indonesia, namely limited resources, lack of regulations or operational guidelines for PPM implementation, lack of commitment from the government and partners in implementing PPM, and lack of communication and coordination between PPM networks so that the PPM network does not function properly. ${ }^{9}$ In this regard, the Health Office is responsible for the PPM network, appoints a PPM coordinator, makes decisions about the formation of the PPM Team, prepares and approves TB patient care procedures and ensures procedures are carried out, monitors and evaluates the implementation of DOTS and other TB program activities, and ensures that the recording system and reporting work. The assessment is used to monitor the achievement of the DOTS program in health care facilities. The indicator for the progress of PPM is the contribution of the TB case finding rate (CNR) and the success rate of treatment in each health facility. A strong commitment from stakeholders, both private and government, in implementing PPM is one of the steps to strengthen PPM. ${ }^{6}$

Furthermore, the data showed that private sector participation in control and care is still low; only 15 health facilities out of 183 private clinics in Pekanbaru were involved in PPM. Therefore, it is necessary to continue to do socialization to improve the quality of PPM. Although $47.4 \%$ of facilities reported that they did not notify TB cases in Zambia, only a quarter of private health facilities could independently report, diagnose, and manage TB cases. More than three-quarters of facilities cannot diagnose or treat tuberculosis cases and refer patients to the public sector. While all private facilities participate in national TB programs either by diagnosing patients or referring them to other facilities for further management, most facilities show no evidence of reporting cases to TB program managers. ${ }^{12}$ Many frontline providers in Asia, particularly in Africa sub-Saharan, are informal, resulting in a low quality of medical care. In these circumstances, the best option is strictly limiting the types of activities allowed by these service providers, training to only a few activities such as symptom screening and referral, and enforcing restrictions with regulations. ${ }^{8}$

The case notification rate (CNR) found was lower than Indonesia's CNR (139 per 100,000 population), ${ }^{13}$ indicating that many TB cases in Pekanbaru have not been detected. The number of case notifications fluctuates every year. However, the average CNR performance after implementing the PPM strategy tends to increase due to improved overall case findings and improved recording and reporting systems. Our findings regarding the success of PPM's contribution to TB case detection align with previous 
studies in Myanmar. ${ }^{14}$ Case Notification Rate is an indicator that shows the number of new TB sufferers found and recorded among 100,000 people in a region. The number of case notifications collected in series will describe increasing or decreasing case finding in TB patients from year to year in a region, health services involved in DOTS services, and the number of TB patients not reported by health care facilities. ${ }^{6}$ Furthermore, training of health workers can increase the number of microbiologically confirmed TB patients. In this regard, the Partnership in Bangladesh significantly increased case notification rates in the project area after implementing the partnership. The increase in the detection of smear-positive TB cases contributes to around $36 \%$ of all TB cases in the region. ${ }^{15}$

Puskesmas plays a role in ensuring the coordination of private clinics in their working areas to detect, record, and report TB cases. Based on this role, Puskesmas that have implemented PPM must be able to increase the number of case notifications. The PPM strategy is considered relevant for countries with a high TB burden in Asia and Africa. According to a WHO report, the contribution of PPM to TB notification between 2012 and 2016 increased by more than 10\% in Indonesia, Bangladesh, India, and the Philippines. PPM contributes between 5\% -56\% for TB notifications. Moreover, research in Myanmar shows that in 2017 PPM contributed $17 \%$ to all TB notifications. ${ }^{1}$ Besides, research in Yogyakarta, Indonesia, explained that the contribution of independent practicing doctors in the notification of TB cases was still low. The involvement of private practitioners has significantly increased TB case detection. Interviews in the study indicated that private practitioners felt involved in the medical management of TB patients. However, most did not report TB cases due to ignorance, lack of socialization, and mandatory TB reporting policies. ${ }^{16}$ Meanwhile, data analysis in Northern Uganda shows an increase in TB case reports in the 10 intervention districts and makes positive trends to achieve national targets. ${ }^{17}$ In relation to it, house-to-house screening for active tuberculosis and establishing tuberculosis diagnostic clinics closer to home and workplaces can increase the detection of tuberculosis cases in areas where the prevalence of the undiagnosed disease is high. ${ }^{18}$

In addition, this study showed that the treatment success rate in Pekanbaru fluctuated every year. Overall, the average success rate of treatment at Puskesmas that has implemented the PPM strategy in Pekanbaru Municipality has not succeeded in achieving the national target of at least $90 \%$. However, the success rate of treatment tends to increase. The achievement of the success rate of treatment has fluctuated and has not yet reached the national target. It was caused by the ineffective implementation of PPM due to various factors such as resources, regulations, communication between health service facilities, etc. Treatment success rate represents the percentage of patients who have recovered and underwent complete treatment among the smear-positive pulmonary TB patients recorded. ${ }^{6}$ Treatment success rates in most countries are generally high after the implementation of PPM. It is proved by marked improvements in the treatment outcomes from private services in some countries after engaging in PPM, although some have not reached the target of the national TB program. ${ }^{19}$ In 2016, the global treatment success rate was $82 \%$. This figure has decreased compared to 2015, where it reached $83 \%$, and in 2016 where it reached $86 \%$. Treatment outcomes are still not in line with increasing notification in some countries. ${ }^{1}$ High or low treatment success rates can be influenced by a variety of factors. The factors can come from the patient, the supervisor swallowing the drug (PMO), and the drug factor. Patient factors can occur as the patient does not comply with the drug, moves to another health service facility, and suffer from drug-resistant TB. The monitoring factor for taking medication can occur since there is no PMO or PMO that is not under supervision. Drug factors can occur due to disruption of the supply of anti-tuberculosis (OAT) drugs. As a result, patients delay or stop treatment, and the quality of OATs decreases due to improper storage. ${ }^{20}$ Puskesmas is the first pillar in the PPM strategy. One of the components in the first pillar is the Puskesmas to establish a network between the DOTS service pillars and other pillars in expanding services for TB patients who are resistant to drugs. In external network services, Puskesmas also coordinates primary health care facilities in their working areas for TB diagnosis, management and loss to follow-up, logistics, contact investigations, and referral of TB cases. Furthermore, the Puskesmas works closely with non-governmental organizations (NGOs), as well as coordinates volunteers to support patient activities and contact investigations. ${ }^{6}$

Based on the explanation of the research above, the strength of this study includes taking primary data from six health centers that have implemented PPM and making longitudinal observations through secondary data. The analysis was carried out both quantitatively and qualitatively to dig for more profound information. Meanwhile, the weakness of this research was the small number of samples with coverage in one city, so that the results cannot be generalized to a broader area. It is necessary to explore further the role of each stakeholder in implementing PPM, conduct intervention studies. assess the achievement of TB control program indicators, and increase PPM's socialization 


\section{CONCLUSION}

PPM has been implemented in Pekanbaru since 2014. In its implementation, Puskesmas has carried out activities following technical guidelines. However, the involvement of private clinics, local government, NGOs, and the community was low. Some of the obstacles in implementing PPM include lack of human resources, collaboration with external networks, and administrative factors. The TB control program indicators, namely the case notification rate (CNR) and treatment success (SR), increased after PPM implementation but had not yet reached the national target.

\section{ACKNOWLEDGEMENT}

This research was carried out with the funding of research grants from the Faculty of Medicine, the University of Riau, in 2019. We would like to thank all informants at the Puskesmas and the Pekanbaru City Health Office for their support in implementing this research.

\section{CONFLICT OF INTEREST}

In the research and article writing process, there was no conflict of interest, either financial or personal, that influenced the results of this study.

\section{REFERENCES}

1. World Health Organization. Global Tuberculosis Report 2017. Geneva: World Health Organization; 2017. Licence: CC BY-NC-SA 3.0 IGO. available at ttp://apps.who.int/iris

2. Ministry of Health Indonesia. Health Indonesia Profile 2018 (Profil Kesehatan Indonesia Tahun) 2018. Jakarta : Ministry of Health of Indonesia. 2019

3. World Health Organization. Global Tuberculosis Report 2018. Geneva:; 2018. Licence: CC BY-NC-SA 3.0 IGO

4. Martínez JA, Kamp N. Strategic Guide for Building Public Private Mix (PPM) Partnerships to Support Tuberculosis Control. Mexiko:USAID; 2011

5. Challenge TB Team. Technical Instructions Application of Public Private Mix Based based on District / City- ( Petunjuk Teknis Penerapan Public Private Mix Berbasis Kabupaten/Kota Area Binaan Challenge TB Jakarta: Ministry of Health. 2018.

6. Ministry of Health of the Republic of Indonesia. National Guideline for The Control of Tuberculosis (Pedoman nasional pengendalian tuberkulosis). Jakarta: Ministry of Health of Indonesia: 2014.

7. Lei X, Liu Q, Escobar E, Philogene J, Zhu H, Wanga Y, Tang S. Public-private Mix for Tuberculosis Care and Control: a Systematic Review. International Journal of Infectious Diseases, 2015. 34: $20-32$. https://doi.org/10.1016/j.ijid.2015.02.015

8. Wells WA, Uplekar M and Pai M. Achieving Systemic and Scalable Private Sector Engagement in Tuberculosis Care and Prevention in Asia. PLoS Med. 2015 (12): 1-10. https://doi.org/10.1371/journal.pmed.1001842

9. Tondong PMA, Mahendradhata YH and Ahmad RA. Evaluation of the Implementation of Public Private Mix for Tuberculosis Control in Ende District East Nusa Tenggara Province Year 2012 (Evaluasi Implementasi Public Private Mix PengendalianTuberkulosis di Kabupaten Ende Provinsi Nusa Tenggara Timur Tahun 2012. J. Kebijak. Kesehat. Indones. JKKI 2014(3): 37-42. https://doi.org/10.22146/jkki.36356

10. Melese M, Habte D, Girma B, Kassie Y, Negash S, Melkeneh K, et.al. Use of Indicators of Standards of Care to Improve Tuberculosis Program Management in Ethiopia. J Clin Tuberc Other Mycobact Dis. 2018.(10) 17-23. https://doi.org/10.1016/i.jctube.2017.12.001

11. Engelbrecht MC, Kigozi G, Rensburg APJV, Rensburg DHCJV. Tuberculosis Infection Control Practices in a High-burden Metro in South Africa : A Perpetual Bane for Efficient Primary Health Care Service Delivery. Afr J Prim Health Care Fam Med . 2018 May 30; 10(1):e1-e6. http://dx.doi.org/10.4102/phcfm.v10i1.1628

12. Chongwe G, Kapata N, Maboshe M, Michelo C. and Babaniyi O. A Survey to Assess the Extent of PublicPrivate Mix DOTS in the Management of Tuberculosis in Zambia. Afr J Prm Health Care Fam Med 2015: 7(1) . http://dx.doi.org/10.4102/phcfm.v7i1.692

13. Ministry of Health Indonesia. Indonesia National TB Program Current Status of Integrated Community Based TB Service Delivery and the Global Fund Work Plan to Find Missing TB cases. 1-39 (2016-2020). Cited 2021 Maret 23. Available at https://www.who.int/tb/features_archive/indonesia_11apr18 
14. Nwe TT, Saw S, Win LL, Mon MM, Griensven JV, Zhou S, et al. Engagement of Public and Private Medical Facilities in Tuberculosis Care in Myanmar: Contributions and Trends Over an Eight-year Period. Infect. Dis. Poverty 2017( 6): 1-7. https://doi.org/10.1186/s40249-017-0337-8

15. Ullah ANZ, Huque R, Husain A, Akter S, Islam A, Newell JN. Effectiveness of Involving the Private Medical Sector in the National TB Control Programme in Bangladesh: Evidence from Mixed Methods. BMJ Open. 2012 (2): 1-8. https://doi.org/10.1136/bmjopen-2012-001534

16. Kurniawati A, Mahendradhata Y, Padmawati RS3 Acceptability Of The Tuberculosis (Tb) Mandatory Notification On Self Private Practitioners And Private Primary Clinics At Yogyakarta City. JKKI 2009; 8(01). 1-9. https://doi.org/10.22146/jkki.37426

17. Karamagi S, Sensalire S, Muhire M, Kisamba H, Byabagambi J, Rahimzai M, et. al. Improving TB Case Notification in Northern Uganda: Evidence of a Quality Improvement-guided Active Case Finding Intervention. BMC Health Serv. Res. 2018. (18):1-12. https://doi.org/10.1186/s12913-018-3786-2

18. Mhimbira FA, Cuevas LE, Dacombe R, Mkopi A, Sinclair D. Interventions to Increase Tuberculosis Case Detection at Primary Health Care or Community-level Services. Cochrane Database of Systematic Reviews 2017 Nov 28; 11(11): CD011432. https://doi.org/10.1002/14651858.CD011432.pub2

19. Malmborg R, Mann G. and Squire S. A Systematic Assessment of the Concept and Practice of Public-private Mix for Tuberculosis Care and Control. Int. J. Equity Health. 2011(10): 49. https://doi.org/10.1186/1475. 9276-10-49

20. Indah M. Tuberkulosis. InfoDATIN (2018). Jakarta. Ministry of Health Indonesia. 2018. Available in http://www.pusdatin.kemkes.go.id/ 